\title{
THE ICC AND HUMAN Rights: The Crime Against Destruction of Cultural Heritage as Part of a Trend Towards GREATER HUMAN RightS INFLUENCE
}

\author{
HAYDEE J. DIJKSTAL ${ }^{*}$
}

\begin{abstract}
A broad examination of the International Criminal Court's jurisprudence suggests a mixed approach to whether international human rights law and considerations influence the proceedings before the Court. Yet, when viewing its record on more discreet areas of human rights consideration, the development of some consistency can be discerned. With the Court's recent prosecutions for acts of destruction of cultural heritage, the role of human rights in international criminal proceedings took center stage. Despite the fact that actions were taken against culturally significant buildings and objects, the Court's approach demonstrates a consistent view of the crime through a human rights lens at all points in the proceedings. The Court's finding that individuals and communities are victims of the attack and that violations of their rights increase the crime's severity, demonstrates a recognition of the integral nature of human rights to the prosecution of this crime.
\end{abstract}

This Article evaluates how the human rights-based approach adopted within the Court's proceedings for the crime of the destruction of cultural heritage fits within the Court's historical approach to human rights considerations, and whether the influence of human rights in these proceeding at such stages as the gravity assessment to sentencing and reparations proceedings is part of a trend towards a more significant relationship with human rights considerations. Reviewing the Court's historical approach to human rights within its case law, two discreet areas of human rights considerations are evaluated; namely, the use of human rights law and jurisprudence to interpret the Court's legal framework and the Court's willingness to engage with human rights concerns within the proceedings. Finally, this Article proposes that while the Court's advancement of a human rights-based approach to the crime of destruction of cultural heritage is emblematic of a trend towards a more prominent role of human rights in the interpretation and application of the Court's legal framework, the Court's approach to human rights claims remains steady and unmoved.

\section{INTRODUCTION}

On September 18, 2015, the International Criminal Court (the "ICC") PreTrial Chamber issued an arrest warrant against Ahmad Al Faqi Al Mahdi for the charge of destruction of cultural heritage under Article 8(2)(e)(iv) of the Rome

* Barrister at 33 Bedford Row Chambers, London, practicing international criminal and human rights law (https://www.33bedfordrow.co.uk/people/dijkstal-haydee). 
Statute. ${ }^{1}$ Significantly, the prosecution solely charged Al Mahdi for his individual criminal responsibility for the war crime of "[i]ntentionally directing attacks against buildings dedicated to religion, education, art, science or charitable purposes, [and] historic monuments." " Early in the proceedings, $\mathrm{Al}$ Mahdi made an admission of guilt for the charge against him of attacking and destroying nine mausoleums and one mosque in Timbuktu. ${ }^{3}$ The trial was concluded with the Trial Chamber's Judgment and Sentence on September 27, 2016, which found that "[i]n the light of the admission of guilt, the hearings held and the evidence brought forward, the Chamber is satisfied beyond reasonable doubt that all the essential facts of the crime charged are proven." With the Trial Chamber issuing a reparations decision in August 2017 and the Appeals Chamber affirming in part while reversing aspects of the order concerning the role of the Trust Fund for Victims and victim anonymity, ${ }^{6}$ the Al Mahdi case was concluded, and he was transferred by the Hague Detention Unit to Scotland in May 2019 to serve his sentence of nine years. ${ }^{7}$

From start to finish, the $\mathrm{Al}$ Mahdi case signified a clear acceptance of the influence of human rights law, jurisprudence, and considerations during its proceedings. Wholly accepting the human link to a crime about destroying buildings and objects, the Court viewed "cultural heritage [as] important not only in itself but also in relation to its human dimension." In finding that an "attack against the Protected Buildings not only destroyed and damaged physical structures" but also " diminished the link and identity the local community had" with such valuable cultural heritage," the Trial Chamber found "the importance of cultural heritage" to be "an essential component of the charges Mr. Al Mahdi is convicted of." 10 The Court's extraordinary reference and reliance on human rights considerations in guiding each step of the proceedings draws the question of whether such an approach is unique to the crime concerned or indicative of a trend towards the more significant influence of human rights.

1. Prosecutor v. Al Mahdi, ICC-01/12-01/15-171, Judgement and Sentence, 7 (Sept. 27, 2016), https://www.icc-cpi.int/courtrecords/cr2016_07244.pdf [https://perma.cc/4MSX-EFFN].

2. Rome Statute of the International Criminal Court (Rome Statute) art. 8(2)(e)(iv), July 1, 2002, 2187 U.N.T.S. 90.

3. Al Mahdi, ICC-01/12-01/15-171, ๆ 7, 98-100.

4. Id. $ๆ 62$.

5. Prosecutor v. Al Mahdi, ICC-01/12-01/15-236, Reparations Order (Aug. 17, 2017), https://www.icc-cpi.int/CourtRecords/CR2017_05117.PDF [https://perma.cc/WNB7-G3HZ].

6. Prosecutor v. Al Mahdi, ICC-01/12-01/15-259-Red2, Judgment on the Appeal of the Victims Against the 'Reparations Order' (Mar. 8, 2018), https:/www.icc-cpi.int/CourtRecords/ CR2018_01623.PDF [https://perma.cc/P6YA-RX43].

7. See Ahmad Al Faqi Al Mahdi transferred to UK prison facility to serve sentence, INT'L CRIM. CT. (May 3, 2019), https://www.icc-cpi.int/Pages/item.aspx?name=pr1451 [https://perma.cc/ 65PK-CG9L].

8. Al Mahadi, ICC-01/12-01/15-236, ๆ 16.

9. Id. ๆ 19.

10. Id. $\ 13$. 
While the crime of destruction of cultural property and heritage could be viewed as particularly suited to human rights influences and opening the door for their more prominent impact on ICC proceedings, the crime's text does not make such an interpretation inevitable. On its face, the crime is one against property with an elevated status of protection under international humanitarian law given that the buildings concerned are "dedicated to religion, education, art, science or charitable purposes, [or are] historic monuments." 11

Historically, the destruction of cultural property and heritage is also a crime rooted in an area of law that has significantly developed beyond special protection of buildings or sites attacked and towards protection aimed at securing the interests and rights of the people who value these sites. ${ }^{12}$ In short, international legal protections for cultural property and heritage have accepted the human link as inseparable from the acts taken against buildings and objects. ${ }^{13}$ Therefore, interpreting and applying the war crime under the Rome Statute in accordance with this framework of developing protections under international law, rather than a strict interpretation of the protections afforded under international humanitarian law, would evidence an increased focus on individuals, and their rights, which are harmed by the destruction of the property and heritage, rather than just the obligations of parties within an armed conflict. Accordingly, the Court's interpretation and application of the crime and its associated proceedings reflect this progression towards viewing acts against protected sites and objects as attacks against the people and communities harmed and affected by the damage and destruction to the property, which is significant to their culture.

The question, therefore, arises as to whether the Court's prosecution of the crime of destruction of cultural heritage comports with the Court's historical approach to human rights law and considerations, and whether jurisprudence in regards to this crime and particularly with the proceedings in the Al Mahdi case demonstrate any trend towards a greater influence of human rights in the proceedings before the Court.

In this regard, the Court's historical and more recent treatment of human rights considerations is assessed to determine whether or not there is a trend

11. Rome Statute, supra note 2, art. 8(2)(e)(iv) See also id. art. 8(2)(b)(ix).

12. See, e.g., Francesco Francioni, The Human Dimension of International Cultural Heritage Law: An Introduction, 22 EUR. J. INT'L L. 9, 13 (2011) (commenting on the developments in protections made within the 1954 Hague Convention for the Protection of Cultural Property in the Event of an Armed Conflict and its First Protocol of 1954 and Second Protocol of 1999); Francesco Francioni \& Federico Lenzerini, The Destruction of the Buddhas of Bamiyan and International Law, 14 EUR. J. INT'L L. 619, 635 (2003) (noting that the World Heritage Convention in 1972 presented "the protection of cultural heritage as a matter of public interest, and not only as part of private property rights"); Patty Gerstenblith, The Destruction of Cultural Heritage: A Crime Against Property or a Crime Against People?, 15 J. Marshall Rev. Intell. Prop. L. 336, 383 (2016) (discussion on developments made to protection within the UNESCO Declaration concerning the International Destruction of Cultural Heritage).

13. Francioni, supra note 12, at 9. 
toward a greater influence of human rights. When considering the Court's relationship with international human rights law, the conclusion often offered as to the Court's approach of openness to being guided by this area of law is that the Court has no set orientation. When considered broadly, the Court's relationship with human rights law and human rights issues has been described as 'inconsistent' whereby a "clear pattern" is "difficult to determine." 14

However, human rights issues and considerations can arise in proceedings in a myriad of ways regarding distinctive issues and requiring unique considerations by the Court. Instead of reviewing human rights considerations as a whole, whereby a range of varied and inconsistent approaches result, a focus on nuanced areas of human rights considerations reveals a degree of patterns and trends in their consideration. Indeed, the Court's use of human rights law and jurisprudence to interpret the Court's legal framework and procedures is very different from the Court's consideration of allegations of human rights violations from such parties as to the defense or victims and how the allegations might affect the Court's proceedings. Both involve consideration of human rights concerns and could require the Court to look to human rights law and jurisprudence but involve very different determinations and consequences.

As a result, this Article examines two ways in which human rights considerations are regularly arising before the Court-first, the role of human rights law in interpreting and applying the Court's statutory framework; and second, human rights considerations that require the Court to weigh in on the commission of human rights allegations. The former approach demonstrates a progressive trend towards a greater human rights role, and the latter maintains a consistent hesitation against engagement.

With a historical trend towards a more significant influence of human rights in guiding the interpretation and application of the Court's legal texts, this shifting perspective is plain in the Court's proceedings on the destruction of cultural heritage. As a central component in the Court's analysis and decision making, the extraordinary influence of human rights in the proceedings concerning cultural heritage are emblematic of the Court's trend towards a more leading role of human rights in the interpretation and application of its own provisions.

\section{THE COURT'S APPROACH TO HUMAN RIGHTS IN PROCEEDINGS CONCERNING Cultural Heritage}

As the ICC's first prosecution to solely focus on the crime of destruction of cultural heritage, the case against Ahmad Al Faqi Al Mahdi was described as a "landmark moment"15 and a "victory for the institution and as a ground-

14. Brianne McGonigle Leyh, Pragmatism Over Principles; The International Criminal Court and a Human Rights-Based Approach to Judicial Interpretation, 41 FORDHAM INT'L L. J. 697, 700-01(2018).

15. Paul Williams and C. Danae Paterson, Tear It All Down: The Significance of the al-Mahdi Case and the War Crime of Destruction of Cultural Heritage, HufFPost (Sept. 30, 2016), 
breaking legal precedent." 16 Described as a "historical first"17 and "a manifestation of the global efforts to bring the perpetrators of cultural heritage crimes to justice," 18 the proceedings demonstrated that "accountability for cultural crimes is possible." 19

Following the prosecution of $\mathrm{Al}$ Mahdi, similar charges under Article 8(2)(e)(iv) of the ICC Statute were brought against Malian national, Al Hassan Ag Abdoul Aziz Ag Mohamed Ag Mahmoud, for his responsibility in attacks against culturally significant buildings in Timbuktu as an alleged member of Ansar Eddine and de facto chief of Islamic police. ${ }^{20}$ Most recently, Alfred Yekatom and Patrice-Edouard Ngaïssona, who were separately charged, and whose cases were subsequently joined, ${ }^{21}$ were prosecuted under Article $8(2)$ (e)(iv) for "intentionally directing attacks against building dedicated to religion" including "Muslim property and religious buildings (mosques)" in the Central African Republic. ${ }^{22}$ The subsequent prosecutions for the same war crime of destruction of cultural heritage have emphasized that the case against Al Mahdi was not a unique or singular instance for addressing crimes against cultural heritage, but a commitment by the Court to hold those most responsible for attacking the culturally significant objects and buildings of communities responsible under international law.

Because the cases against Al Hassan, Yekatom, and Ngaïssona are in the early stages with trial proceedings against Al Hassan commencing on July 14,

https://www.huffpost.com/entry/tear-it-all-down-the-significance-of-the-al-mahdi_b_ 57e93786e4b09f67131e4b52 [https://perma.cc/MD8B-QSX9].

16. Milena Sterio, Individual Criminal Responsibility for the Destruction of Religious and Historic Buildings: The Al Mahdi Case, 49 CASE W. RSRV. J. of INT'L L. 63, 66 (2017).

17. Marina Lostal, The Misplaced Emphasis on the Intangible Dimension of Cultural Heritage in the Al Mahdi Case at the ICC, 1 MCGill J. InT'L L. \& Legal Pluralism 45, 52 (2017).

18. Karolina Wierczynska \& Andrzej Jakubowsk, Individual Responsibility for Deliberate Destruction of Cultural Heritage: Contextualizing the ICC Judgment in the Al-Mahdi Case, 16 ChineSE J. INT'L L. 695, 699 (2017).

19. Mark Kersten, The al-Mahdi Case is a Breakthrough for the International Criminal Court, Just. Conflict (Aug. 25, 2016) https://justiceinconflict.org/2016/08/25/the-al-mahdi-caseis-a-breakthrough-for-the-international-criminal-court/ [https://perma.cc/6TPE-WMGY].

20. Prosecutor v. Al Hassan, ICC-01/12-01/18-2, Warrant of Arrest for Al Hassan Ag Abdoul Aziz Ag Mohamed Ag Mahmoud, Al Hassan (Mar. 27, 2018), https://www.icccpi.int/CourtRecords/CR2018_02547.PDF [https://perma.cc/6LX5-FWPA].

21. Prosecutor v. Yekatom, ICC-01/14-01/18-87, Decision on the Joinder of the Cases Against Alfred Yekatom and Patrice-Edouard Ngaïssona and Other Related Matters (Feb. 20, 2019), https://www.icc-cpi.int/CourtRecords/CR2019_00948.PDF[https://perma.cc/YK8V-HQBE].

22. Prosecutor v. Yekatom, ICC-01/14-01/18-1-Red, Public Redacted Version of "Warrant of Arrest for Alfred Yekatom," - 2, 10 (Nov. 17, 2018), https://www.icc-cpi.int/CourtRecords/ CR2018_05412.PDF [https://perma.cc/DW3C-LYB5]; Prosecutor v. Ngaïssona, ICC-01/14-02/182-Red, Public Redacted Version of 'Warrant of Arrest for Patrice-Edouard Ngaïssona,' \ 2, 10 (Dec. 13, 2018), https://www.legal-tools.org/doc/5185e5/pdf/ [https://perma.cc/UYF3-2GNF]. 
$2020,{ }^{23}$ and the trial against Yekatom and Ngaïssona only to open in February $2021,{ }^{24}$ the proceedings against Al Mahdi remain the most comprehensive example of how the prosecution for the crime of destroying cultural heritage at the ICC has influenced the Court's relationship with human rights. An examination of the proceedings from start to finish in Al Mahdi demonstrates that human rights were a guiding force in both the Prosecution and Chamber's approach to the interpretation and application of Article 8(2)(e)(iv).

\section{i. Al Mahdi: Human rights Considerations in the Preliminary Examination and Investigation Stage}

To start, the Prosecution's approach to the investigation and prosecution of Al Mahdi demonstrates how human rights considerations heavily influenced the interpretation and application of the war crime of destruction of cultural heritage before the Court. This influence is discernible in the gravity assessment within the Preliminary Examination in the Situation in Mali and the subsequent charging decision against Al Mahdi.

The Prosecution's periodic report on the progress of the Preliminary Examination in Mali advances its analysis of information received as to "a series of attacks in the city of Timbuktu against at least nine mausoleums, two mosques and two historical monuments with designated World Cultural Heritage status," and its position that there is "a reasonable basis to believe that . . war crimes have been committed" including "intentionally directing attacks against protected objects, including religious buildings and historic monuments under article $8(2)(e)(i v) . "{ }^{25}$ In addition to considering relevant war crimes, the Prosecution's expressed consideration of whether crimes against humanity are applicable is notable. While its analysis ultimately did not result in such a charge, the Court still asserted that its "assessment remains ongoing and may be revisited on the basis of new facts or information." ${ }^{26}$ Moreover, even at the conclusion of the Preliminary Examination and upon initiation of the formal investigation, the Prosecution held the same position within its Article 53(1) Report. ${ }^{27}$

Consideration by the ICC Prosecution of acts against cultural heritage as a crime against humanity is consistent with the practice of the International Criminal Tribunal for the Former Yugoslavia, which primarily charged such acts as crimes against humanity of persecution, including, for example, in the cases

23. Al Hassan trial opens at International Criminal Court, INT'L CRIM. CT., (July 14, 2020), https://www.icc-cpi.int/Pages/item.aspx?name=pr1531 [https://perma.cc/X7UT-W9Q5].

24. Yekatom and Ngaïssona Case: Trial to Open on 9 February 2021, INT'L CRIM. CT. (July 16, 2020), https://www.icc-cpi.int/Pages/item.aspx?name=pr1532 [https://perma.cc/E4J8-E5U6].

25. Office of the Prosecutor, Report on Preliminary Examination Activities 2012 175,179 (2012).

26. Id. at 181.

27. Office of the Prosecutor, Situation in Mali Article 53(1) Report 128 (2013) [hereinafter SitUATION IN MALI]. 
of Blaskic, ${ }^{28}$ Krajisnik, ${ }^{29}$ Kordić and Čerkez, ${ }^{30}$ Jokic, ${ }^{31}$ Naletilic, ${ }^{32}$ Prlić, ${ }^{33}$ Brdanin ${ }^{34}$ and Milutinović. ${ }^{35}$ Therefore, while charging Al Mahdi's acts as a crime against humanity of persecution would be a first at the ICC, it would be well grounded in international criminal law precedent as a manner of addressing individual criminal responsibility for cultural heritage attacked and destroyed.

In the end, Al Mahdi's prosecution proceeded with charging one count of the war crime under Article 8(2)(e)(iv); a crime formulated as a "serious violation[] of the laws and customs applicable in armed conflicts[,]"36 and based on principles of international humanitarian law stemming from the 1949 Geneva Conventions and including its Additional Protocols I and II which prohibit "acts of hostility directed against the historic monuments, works of art or places of worship which constitute the cultural or spiritual heritage of peoples." ${ }^{37}$ This choice is significant given the historical development of the legal protections of cultural heritage, which began in the $1800 \mathrm{~s}$, as protections centered around the protection of cultural property and the rights of ownership or sovereign rights of a State, and only later developed to protections of cultural 'heritage,' instead of

28. Prosecutor v. Blaskic, Case No. IT-95-14-T, Judgment, ๆ甲 228, 233 (Int'l. Crim. Trib. for the Former Yugoslavia Mar. 3, 2000), https://www.icty.org/x/cases/blaskic/tjug/en/blatj000303e.pdf [https://perma.cc/GR8Y-M4TZ].

29. Prosecutor v. Krajisnik, Case No. IT-00-39-T, Judgment, 9 甲 781-2 (Int'1. Crim. Trib. for the Former Yugoslavia Sept. 27, 2006), https://www.icty.org/en/case/krajisnik [https://perma.cc/ FYC2-4ZWV].

30. Prosecutor v. Kordić \& Čerkez, Case No. IT-95-14/2-T, Judgment, 『 207 (Int'l. Crim. Trib. for the Former Yugoslavia Feb. 26, 2001), https://www.icty.org/x/cases/kordic_cerkez/acjug/ en/cer-aj041217e.pdf [https://perma.cc/VEU2-F7MH].

31. Prosecutor v. Jokic, Case No. IT-01-42/1-S, Sentencing Judgment, ๆథ 51, 53 (Int'l. Crim. Trib. for the Former Yugoslavia Mar. 18, 2004), https://www.icty.org/x/cases/miodrag_jokic/tjug/ en/jok-sj040318e.pdf [https://perma.cc/BQ8P-VWS3].

32. Prosecutor v. Naletilic, Case No. IT-98-34-T, Judgment, ๆๆ 704, 709, 713, 763 (Int'1. Crim. Trib. for the Former Yugoslavia Mar. 31, 2003), https://www.icty.org/x/cases/naletilic martinovic/acjug/en/nal-aj060503e.pdf [https://perma.cc/H535-KB9W].

33. Prosecutor v. Prlić, Case No. IT-04-74-T, Judgment, 22-23, \178 (Int’l. Crim. Trib. for the Former Yugoslavia May 29, 2013), https://www.icty.org/x/cases/prlic/tjug/en/130529-3.pdf [https://perma.cc/VT8M-ECGC].

34. Prosecutor v. Brdanin, Case No. IT-99-36-T, Judgment, ๆๆ 15(c), 1082 (Int'l. Crim. Trib. for the Former Yugoslavia Sept. 1, 2004), https://www.icty.org/x/cases/brdanin/tjug/en/brdtj040901e.pdf [https://perma.cc/3QJZ-S6DT].

35. Prosecutor v. Milutinović, et al., Case No. IT-05-87-T, Judgment, ๆ 206 (Int'l. Crim. Trib. for the Former Yugoslavia Feb. 26, 2009), https://www.icty.org/x/cases/milutinovic/tjug/en/ jud090226-elof4.pdf [https://perma.cc/9678-BD7S].

36. Rome Statute, supra note 2, art. 8(2)(b).

37. Protocol Additional to the Geneva Conventions of Aug. 12 1949, and Relating to the Protection of Victims of Non-International Armed Conflicts art. 16, June 8, 1977, 1125 U.N.T.S. 609; Protocol Additional to the Geneva Conventions of Aug. 12, 1949, and Relating to the Protection of Victims of International Armed Conflicts art. 53(a), June 8, 1977, 1125 U.N.T.S. 3. 
cultural 'property' and a recognition that acts of damage and destruction against culturally significant objects and buildings are crimes against the individuals who value the sites. ${ }^{38}$ With this significant shift attributed to the 1954 Hague Convention for the Protection of Cultural Property in the Event of an Armed Conflict and its First Protocol of 1954 and Second Protocol of $1999,{ }^{39}$ the earlier established Geneva Conventions and its Additional Protocols I and II, for which the crimes under Article 8 are based, are noted as leaning in focus towards the obligations of armed forces in regards to cultural property. ${ }^{40}$

Had the Prosecution decided to follow the well-established lead of the International Criminal Tribunal for the Former Yugoslavia (ICTY) in charging Al Mahdi's acts as a crime against humanity of persecution, a cursory review might have assessed such a choice to be the more human rights-based approach to charging considering that the war crime of destruction of cultural heritage under Article 8 is based on post-WWII international instruments which had not fully developed towards recognizing the rights and interest at play when protecting culturally significant objects. Instead, the Prosecution's approach to the war crime charged demonstrated a human rights-based interpretation of the war crime, which expanded the interpretation of the crime beyond a strict formulation rooted in the parties' obligation to armed conflict over cultural property. The Prosecution's approach demonstrated that human rights considerations guided its interpretation of the crime and contributed to a broader understanding of the crime, which considers the human rights of individuals affected by the acts of destruction. Indeed, in the Prosecution's press release upon the transfer of Al Mahdi to The Hague on 26 September 2015, it stated that the charge against him was not only about the destruction of irreplaceable historic monuments," but also "about a callous assault on the dignity and identity of entire populations, and their religious and historical roots." ${ }^{41}$

The Prosecution's willingness to be guided by human rights considerations is also demonstrated in its gravity assessment within the Article 51(3) Report that analyzed whether the crime for which it found a reasonable basis to believe was committed, such that an investigation is warranted, is of sufficient gravity under

38. See Joshua E. Kastenberg, The Legal Regime for Protecting Cultural Property During Armed Conflict, 42 A.F. L. REV. 277, 280-299 (1997); Stanislaw E. Nahlik, International Law and the Protection of Cultural Property in Armed Conflicts, 27 Hastings L.J. 1069, 1070-1078 (1976).

39. See Corine Wegener, The 1954 Hague Convention and Preserving Cultural Heritage, ARCHAEOlOGiCAL INST. AM. (Oct. 19, 2010), https://www.archaeological.org/the-1954-hagueconvention-and-preserving-cultural-heritage/ [https://perma.cc/56AK-KKKG]; Francioni, supra note 12 , at 13

40. James A.R. Nafziger, International Penal Aspects of Protecting Cultural Property, 19 INT'L L. 835, 839 (1985).

41. Statement of the Prosecutor of the International Criminal Court, Fatou Bensouda, Following the Transfer of the First Suspect in the Mali Investigation: "Intentional Attacks Against Historic Monuments and Buildings Dedicated to Religion are Grave Crimes", INT'L CRIM. CT., (Sept. 26, 2015), https://www.icc-cpi.int/pages/item.aspx?name=otp-stat-26-09-2015 [https:// perma.cc/SX3L-H4GW]. 
Article 17(1)(d) to be admissible before the Court. ${ }^{42}$ The Report assessed the "quantitative and qualitative considerations" of the acts of destruction of cultural heritage in Mali, including the "scale, nature, manner of commission of the crimes, and their impact" 43 in order to find that "the destruction of religious and historical sites in Timbuktu appears grave enough to justify further action by the Court." 44

The Court also explicitly examined the interests and rights of individuals affected by the crime as part of the gravity analysis. For example, in assessing the nature of the crime, the Prosecution recognized the human link to the acts which were committed against buildings and property in Mali by acknowledging that it is "undoubtedly the case of the religious and historical buildings in Timbuktu" that their "value transcends geographical boundaries, and [is] intimately associated with the history and culture of the people." ${ }^{95}$ Similarly, the Prosecution's consideration of the impact of the crime looked to the UN Secretary-General's submission that the destroyed sites are "part of the indivisible heritage of humanity" and to information that "destruction of religious and historical World Heritage sites in Timbuktu appears to have shocked the conscience of humanity." 46

These considerations on the gravity of the war crime charged reinforce that the Prosecution's approach to a war crime, strictly formulated within its text as a crime against property, is guided by human rights considerations that recognize the human element to the crime. The Prosecution's recognition of the war crime goes beyond being a crime merely against cultural property. It views the war crime as a crime against cultural heritage, thus resembling a crime that is against individuals, communities, and all of humanity. ${ }^{47}$ Given that "one of the main features of crimes against humanity is their impact not just upon the immediate victims but also on all humanity," ${ }^{48}$ it appears that the Prosecution in the case of charging $\mathrm{Al}$ Mahdi viewed the war crime of destruction of cultural heritage in similar regard.

\section{ii. Al Mahdi: Human Rights Considerations in the Confirmation of Charges Proceedings}

The confirmation of charges proceeding in the case against Al Mahdi, which under Article 61(7) requires that a hearing is held after the surrender or appearance of the accused to confirm "whether there is sufficient evidence to

42. The Office of the Prosecutor, supra note 27, \142.

43. Id. 143.

44. Id. 160.

45. Id. 155 (partially quoting Y. Sandoz et al., "Commentary on the Additional Protocols of 8 June 1977 to the Geneva Conventions of 12 August 1949," nos. $2064 \mathrm{ff}$ ).

46. Id. ๆๆ 157, 159.

47. Id.

48. Yaron Gottlieb, Attacks Against Cultural Heritage as a Crime Against Humanity, 52 CASE W. RsRv. J. InT’L L. 287, 『 302 (2020). 
establish substantial grounds to believe that the person committed each of the crimes charged," were also influenced by the human element and human rights of those affected by the crime. ${ }^{49}$ During Prosecutor Fatou Bensouda's remarks on the crime charged against Al Mahdi, she set out the crime within the context of the human rights interests affected, stating:

Let us be clear: What is at stake here is not just walls and stones. The destroyed mausoleums were important from a religious point of view, from an historical point of view and from an identity point of view. Such an attack against buildings dedicated to religion and historic monuments falls into the category of crimes that destroy the roots of an entire people and profoundly and irremediably affect its social practices and structures. This is precisely why such acts constitute a crime under Article 8(2)(e)(iv) of the Rome Statute. ${ }^{50}$

In addressing the evidence and information relied upon by the Prosecution for the crime charged, the Pre-Trial Chamber, in its confirmation decision, confirmed that this information made clear that the buildings and structures damaged and destroyed were dedicated to religion or of a historical nature, as prescribed in the language of Article 8(2)(e)(iv). ${ }^{51}$ Notably, the Pre-Trial Chamber also went on to note, as part of its analysis, that the sites were "regarded and protected as a significant part of the cultural heritage of Timbuktu and of Mali," and played "an important role in the life" of these communities." turn, looked to this evidence of the importance the cultural heritage destroyed, as well as the "unanimous outcry of the international community and individuals concerned," to support a finding of the "seriousness of the acts." the Pre-Trial Chamber's language is more confined to the language of Article $8(2)$ (e)(iv) than later judicial decisions in the Al Mahdi case, for example, by consistently referring to the sites attacked as "buildings/structures," but its recognition of the human link to these physical buildings and structures is notable.

\section{iii. Al Mahdi: Human Rights Considerations in the Court's Judgment and Sentence}

The influence of human rights considerations within the decisions of the Chamber is also evident, most prominently within the Trial Chamber's Judgment

49. Rome Statute, supra note 2, art. 61(1), (7).

50. Prosecutor v. Al Mahdi, ICC-01/12-01/15-T-2-Red2-ENG, Transcript of Confirmation of Charges Hearing, $1 \uparrow 13,16-22$ (Mar.1, 2016).

51. Prosecutor v. Al Mahdi, ICC-01/12-01/15-84-Red, Decision on the Confirmation of Charges Against Ahmad Al Faqi Al Mahdi, 99 36, 39 (Mar. 24, 2016), https://www.icccpi.int/CourtRecords/CR2016_02424.PDF [https://perma.cc/7HUL-Q2R8].

52. Id.

53. Id. ๆ 39. 
and Sentence, ${ }^{54}$ and Reparations Order..$^{55}$

The Trial Chamber's decision of September 27, 2016, on judgment and sentence following Al Mahdi's admission of guilt demonstrates a willingness to take into account human rights considerations in its interpretation and application of the crime charged and its decision on the length of Al Mahdi's sentence. In finding that "all the elements for the war crime of attacking protected objects are established," the Chamber spoke to the value of the cultural heritage Al Mahdi was alleged to have destroyed and damaged. ${ }^{56}$ The Chamber held that "[a]ttacking these mausoleums and mosques was clearly an affront to ... values" including "their special importance to international cultural heritage," and that they are "indispensable to the dignity of man and constitute a sacred duty which all the nations must fulfil in a spirit of mutual assistance and concern." 57

Within the same decision, the Chamber also considered sentencing, and in doing so, weighed the gravity of the crime charged, and for which the Chamber found the essential facts and elements were proven." ${ }^{58}$ The Trial Chamber's assessment of gravity considered the "extent of damage caused, the nature of the unlawful behaviour and, to a certain extent, the circumstances of the time, place and manner," and notably began by noting that Al Mahdi was "not charged with crimes against persons but with a crime against property." ${ }^{.59}$ Such a statement would suggest that the human link to the crime did not influence the Chamber. Instead, it solely viewed the crimes as a matter of property damage; yet, its analysis of the factors influencing gravity demonstrates that the Chamber did, in fact, examine these factors in the context of the crime's human impact.

For example, in examining the "extent of the damage" caused by the crime, the Chamber's analysis included the extent to which the crime harmed people and communities, a foray into determining substantive issues of human rights affected. After stating that the charge against Al Mahdi was not a crime against persons but a crime against property, the Chamber immediately went on to find that "the targeted buildings were not only religious buildings but had also a symbolic and emotional value for the inhabitants of Timbuktu, ${ }^{, 60}$ while also relying upon a witness who asserted that the acts of destruction "aimed at breaking the soul of the people of Timbuktu." ${ }^{61}$ The Chamber found it relevant to "assessing the gravity of the crime committed" to consider that

54. See Prosecutor v. Al Mahadi, ICC-01/12-01/15-171, Judgement and Sentence (Sept. 27, 2016), https://www.icc-cpi.int/courtrecords/cr2016_07244.pdf [https://perma.cc/4MSX-EFFN].

55. See Prosecutor v. Al Mahdi, ICC-01/12-01/15-236, Reparations Order (Aug. 17, 2017), https://www.icc-cpi.int/CourtRecords/CR2017_05117.PDF [https://perma.cc/WNB7-G3HZ].

56. Al Mahadi, ICC-01/12-01/15-171, ๆ 52.

57. Id. (citing Constitution of the United Nations Educational, Scientific and Cultural Organization, 16 Nov. 1945, preamble).

58. Id. ๆๆ 62-3, 76-82.

59. Id. $\uparrow 77$.

60. Id. $\ 79$.

61. Id. $\ 80$. 
Timbuktu is at the heart of Mali's cultural heritage, in particular thanks to its manuscripts and to the mausoleums of the saints. The mausoleums reflected part of Timbuktu's history and its role in the expansion of Islam. They were of great importance to the people of Timbuktu, who admired them and were attached to them. They reflected their commitment to Islam and played a psychological role to the extent of being perceived as protecting the people of Timbuktu .. . The mausoleums were among the most cherished buildings of the city and they were visited by the inhabitants of the city, who used them as a place for prayer while some used them as pilgrimage locations. ${ }^{62}$

The Chamber went on to highlight that the protected status of the destroyed sites elevated the gravity of the crimes due to the far-reaching impact of the crimes, which "not only affect the direct victims of the crimes, namely the faithful and inhabitants of Timbuktu, but also people throughout Mali and the international community." ${ }^{93}$ The Chamber further considered the religious nature and motive of the crimes as increasing gravity, and particularly that the alleged perpetrators within Ansar Dine and AQIM "decided to destroy the sites to stop these prohibited [religious] practices" of the inhabitants of Timbuktu.

Last, it is notable that in considering the mitigating and aggravating factors and circumstances of the crime for the purpose of determining Al Mahdi's Sentence, the Chamber found that victims of the crime suffered "moral harm" or non-pecuniary harm. ${ }^{64}$ This finding of the "mental pain and anguish" of victims not only acknowledged the harm suffered by humans as a result of destroying protected buildings and objects but opened the door, as detailed further below, to reparations awards to be granted to victims for the "moral harm" of "disruption of culture. ${ }^{65}$

In concluding that "the crime for which Mr. Al Mahdi is convicted is of significant gravity," and indicating that moral harm could be assessed for the victims' pain, anguish, and disruption of their culture, the Chamber's engagement with human rights considerations could be noted as moving beyond that ensuring consistency with human rights norms to a relationship guided by human rights concerns of the victims. ${ }^{66}$

\section{iv. Al Mahdi: Human Rights Considerations in the Reparations Proceedings}

Most prominently, the Trial Chamber's Reparations Order of August 17,

62. Id. $\uparrow 78$.

63. Id. 980.

64. Id. $\uparrow 108$.

65. See Prosecutor v. Al Mahdi, ICC-01/12-01/15-236, Reparations Order, \ 85 (Aug. 17, 2017), https://www.icc-cpi.int/CourtRecords/CR2017_05117.PDF [https://perma.cc/WNB7G3HZ].

66. Emma Irving, The Other Side of the Article 21(3) Coin: Human Rights in the Rome Statute and the Limits of Article 21(3), 32 LEIDEN J. INT'L L. 838, 838-9 (2019) (citation omitted). 
2017, included perhaps the strongest nod towards a greater role for human rights considerations in the proceeding concerning the destruction of cultural heritage.

Significantly, the Trial Chamber interpreted Article 8(2)(e)(iv) such that "the importance of cultural heritage" must be viewed as "an essential component of the charges Mr. Al Mahdi is convicted of." ${ }^{\circ 7}$ The Chamber recognizes that "cultural heritage is important not only in itself but also in relation to its human dimension." ${ }^{68}$ Specific to Al Mahdi's case, the Chamber acknowledges that the "attack against the Protected Buildings not only destroyed and damaged physical structures" but " diminished the link and identity the local community had' with such valuable cultural heritage." ${ }^{69}$ It is a position that is apostate to the same Trial Chamber's former statement that Al Mahdi was "not charged with crimes against persons but with a crime against property"70 and demonstrates a progression towards human rights influencing the interpretation of the war crime of destruction of cultural heritage.

In firmly embracing the human link to the crime in reparations proceedings, the Chamber's approach to victim participation and reparations awards further demonstrates its consideration of human rights issues. Although the Trial Chamber's judgment found that Al Mahdi's "common plan underlying this conviction was to attack these sites only" and not to commit "crimes against persons," $" 71$ it is also significantly determined that individuals and communities may be recognized as direct victims of Al Mahdi's crimes. ${ }^{72}$ For the purpose of reparations, the Trial Chamber found that individuals within the "the community of Timbuktu suffered disproportionately more harm as a result of the attack on the Protected Building." ${ }^{.73}$ Therefore, direct victims of Al Mahdi's crimes included "organisations or persons ordinarily residing in Timbuktu at the time of the commission of the crimes or otherwise so closely related to the city that they can be considered to be part of this community at the time of the attack." ${ }^{.74}$

The Chamber's recognition of individuals and organizations as the direct victims of crimes committed against physical buildings and objects is evidence of the Court's observance of human rights consideration within the reparations proceedings and confirmation that the crimes cannot be separated from the people and communities whose culture and religion make the buildings and objects destroyed significant. In fact, the Chamber explicitly references human rights law in looking to the "importance of the human right to cultural life and its physical embodiments" regarding the acts at issue ${ }^{75}$ and relying upon sources that

67. Al Mahdi, ICC-01/12-01/15-236, ๆ 13.

68. Id. $\llbracket 16$.

69. Id. 19.

70. Prosecutor v. Al Mahdi, ICC-01/12-01/15-171, Judgment and Sentence, 77 (Sept. 27, 2016), https://www.icc-cpi.int/CourtRecords/CR2016_07244.PDF [https://perma.cc/VP9Q-CDC2].

71. Al Mahdi, ICC-01/12-01/15-236, ๆ 93.

72. Id. 1 \ 51-56.

73. $I d . \rrbracket 52$.

74. Id. 56.

75. Id. ๆ 14. 
underscore how destroying cultural heritage deprives a community of its fundamental human rights. ${ }^{76}$ Here, the Chamber displays a willingness to engage with questions of human rights and the potential violations of these norms.

The Chamber's acceptance that the "destruction of cultural heritage erases part of the heritage of all humankind" and "acknowledge[ment] [of] the suffering endured by the Malian community and the international community as a whole as a result of the destruction of the Protected Buildings" in Timbuktu, further emphasizes the broad scope with which the Chamber viewed the human element of the crime. Although the Chamber "limit[ed] its assessment of the various kinds of harm" for the purpose of reparations "only to the harm suffered by or within the community of Timbuktu," the acknowledgment of the impact and harm to the international community and humankind as a whole, indicates the degree to which human rights issues were taken into consideration within the proceedings.

Last, the Chamber's recognition of the type of harm suffered by the victims further speaks to the human rights approach adopted. In assessing that the types of harm suffered by the victims include "moral" or non-pecuniary harm suffered by direct and indirect victims, the Chamber relied upon international human rights law and jurisprudence, including the case law of the Inter-American Court of Human Rights, to define moral harm in regards to the crimes committed as not only "mental pain and anguish" for loss of childhood, opportunities and relationships due to the attacks, but also "disruption of culture." relied upon the IACHR's case law to support a finding of the causal link between Al Mahdi's crimes and victims' moral harm, and how acts that violate indigenous communities' right to property or right to practice cultural ceremonies, rights, and traditions risk these communities "suffering irreparable damage to their cultural identity and life and to the cultural heritage to be passed onto future generations" such that reparations or damages are warranted. ${ }^{78}$

From start to finish, the proceedings against Al Mahdi for the destruction of cultural heritage demonstrate a willingness to engage in human rights issues and concerns, as well as a commitment to interpreting and applying not only the war

76. Id. I 14 (citing Prosecutor v. Al Mahdi, ICC-01/12-01/15-214-AnxII-Red2, Expert Report-Reparations Phase: Dr. Marina Lostal, $\uparrow \uparrow$ 44-48 (Apr. 28, 2017) (“Cultural heritage plays a central role in the way communities define themselves and bond together, and how they identify with their past and contemplate their future") (quoting Prosecutor v. Al Mahdi, ICC-01/12-01/15194, UNESCO Amicus Curiae Observation, 11 (Dec. 2, 2016) ("the loss of heritage during times of conflict can deprive a community of its identity and memory, as well as the physical testimony of its past. Those destroying cultural heritage seek to disrupt the social fabric of societies."))).

77. Id. 95 (citing Case of the Yakye Aza Indigenous Community v. Paraguay, Judgment: Merits, Reparations and Costs, Judgment, Inter-Am. Ct. H.R., ๆ 2, 156 (June 17, 2005)); Case of the Plan de Sanchez Massacre v. Guatemala, Reparations, Judgment, InTER-Am. Ct. H.R., ๆ 2 (Nov. 19, 2004).

78. See Case of the Yakye Aza Indigenous Community v. Paraguay, Merits, Reparations and Costs, Judgment, InTER-Am CT. H.R., $₫ 203$ (June 17, 2005); Case of the Plan de Sanchez Massacre v. Guatemala, Reparations, Judgment, InTER-Am Ct. H.R., $\mid 2$ (Nov. 19, 2004). 
crime under Article 8(2)(e)(iv) but also the Court's provisions on the gravity analysis, sentencing, rights of victims and reparations regime "through the lens of human rights." 79

\section{THE COURT’S HISTORICAL APPROACH TO HUMAN RIGHTS}

What emerges from the Al Mahdi proceedings is evidence of the Court's extraordinary approach to human rights considerations. By analyzing the war crime under Article 8(2)(e)(iv) through a human rights lens, and consistently framing the crime as acts against the cultural rights of individuals, communities, and humanity, while also voicing the importance of the human rights affected by the commission of the war crime, the Court underlines how human rights interests are a key component to its understanding of the crime alleged and central to decisions made.

The question arises as to whether the Court's reliance on human rights within its prosecution of the crime of destruction of cultural heritage comports with the Court's historical approach to human rights law and considerations, and whether it demonstrates any trend towards a more significant influence of human rights in the proceedings before the Court.

There are at least two ways that human rights considerations regularly arise before the Court. The first analysis considers the role of human rights law in interpreting and applying the Court's statutory framework. The second regards human rights considerations requiring the Court to weigh in on the commission of human rights allegations. It is assessed whether the Court has historically demonstrated a consistent approach to each discreet human rights issue and if the Court's considerable deference to human rights for the crime of destruction of cultural heritage is indicative of a trend towards a more significant influence of human rights in regards to each.

\section{The Court's Approach to Human Rights for Interpreting and Applying the Court's Legal Framework}

When examining the Court's engagement with human rights considerations, the willingness of the Court to be influenced by international human rights law and jurisprudence when interpreting and applying the Court's statutory framework is fundamental.

Central to this analysis is the Court's interaction with Article 21(3) of the Rome Statute and whether a consistent approach to this provision has been adopted. Article 21 of the Rome Statute speaks to the applicable law before the Court, with its first provisions setting out a hierarchy of applicable law to be relied upon by the Court. Its second provision indicates that the Court's precedent

79. Prosecutor v. Al Mahdi, ICC-01/12-01/15-214-Anx1-Red3, Expert Appointed by the International Criminal Court, U.N. Special Rapporteur in the Field of Cultural Rights, Karima Bennoune, at 12 (Aug. 14, 2017), https://www.icc-cpi.int/RelatedRecords/CR2017_05022.pdf [https://perma.cc/W9DX-U44H]. 
may be informative. ${ }^{80}$ It is Article 21(3) which tethers international human rights law to the work of the Court, stating:

The application and interpretation of law pursuant to this article must be consistent with internationally recognized human rights, and be without any adverse distinction founded on grounds such as gender as defined in article 7, paragraph 3, age, race, colour, language, religion or belief, political or other opinion, national, ethnic or social origin, wealth, birth or other status. ${ }^{81}$

Article 21(3) regards the question of how the Court approaches international human rights law. Although Article 21(3) does not offer international human rights law as a source of law to be applied among the hierarchy of applicable laws set out in Article 21(1), it has been described as creating "a human rights consistency test." ${ }^{2}$

As such, the Court's approach and interpretation of this provision provide insight. However, commentary on the Court's interpretation of Article 21(3) and the provision's applicability and degree of influence has largely reflected that the Court "is yet to reflect a consistent understanding" of the interpretation of Article $21(3){ }^{83}$

Jurisprudence reveals that the Court's approach is rooted in a consistent understanding of human rights' underlying role and that inconsistency with this understanding appears with instances giving greater deference to the influence of human rights. Thus, on the one hand, the Court has progressively developed a consistent position that Article 21(3) should be interpreted as meaning that "the Statute, Rules of Procedure and Evidence and other subsidiary sources of law set out in article 21(1) will always have to produce a result compatible with internationally recognized human rights." ${ }^{~} 84$ On the other hand, the achievement of consistency on this position has been broken by developing jurisprudence which not only views human rights as a tool for ensuring consistency but takes human rights' influence a step further to view it as guiding the interpretation and application of the Court's legal texts in a manner more consistent with viewing human rights as a source of law.

The latter interpretation of the role of human rights signifies a departure from the language of Article 21, which does not offer international human rights law as a source of law to be applied among the hierarchy of applicable laws set out

80. Rome Statute, supra note 2, art. 21(1),21(2).

81. Id. art. 21(3).

82. Irving, supra note 66 , at $838-9$.

83. K.J. ZEEGERS, INTERNATIONAL CRIMINAL TRIBUNALS AND HUMAN RIGHTS LAW: ADHERENCE AND CONTEXTUALIZATION 87-8 (2015) (citing Rebecca Young, Internationally Recognized Human Rights' Before the International Criminal Court, 60 INT'L \& CoMP. L. Q. 189208, (2001)).

84. Gilbert Bitti, Article 21 of the Statute of the International Criminal Court and the Treatment of Sources of Law in the Jurisprudence of the ICC, in THE EMERGING PRACTICE OF THE INTERNATIONAL CRIMINAL COURT 303 (Carsten Stahn \& Goran Suiter eds., 2009). 
in Article 21(1), but merely a tool to ensure that the interpretation and application of the Court's legal texts are not in conflict with human rights norms as provided in Article 21(3). It disrupts the human rights approach as a 'consistency test' and expands international human rights law's role by allowing it to be more akin to a guide than a point of reference for consistency. While it is clear ambiguity has persisted, this inconsistency suggests a trend in the scope of human rights' applicability.

\section{i. The Court's Interpretation and Application of Article 21(3): Historical Approach}

The Court's understanding of Article 21(3) as a provision that grounds human rights in the Court's work is demonstrated in numerous decisions. The Court's early case law on Article 21(3) affirmed its interpretative nature, ${ }^{85}$ and it interpreted the provision as setting a "general principle of interpretation" for which the "contours of the statutory framework provided for in the Statute, the Rules and the Regulations" are to be determined. ${ }^{86}$ A measure of inconsistency emanated from one view of human rights norms under Article 21(3) as a "'gapfilling' mechanism" in the Statute, the Elements of Crimes and the Rules," 88 but this more limited approach to the role of Article 21(3) "disappeared from later case law of the Court." ${ }^{89}$ Instead, a firm recognition developed of the provision's applicability as "a more general rule which must govern both the interpretation and application of the sources of law expressly identified in paragraphs 1 and 2." $" 90$

Commentary has pointed to Article 21(3) as "provid[ing] a strong directive for the Court to interpret all legal norms .. in such a way as would comport with human rights norms," but also raised that the "ordinary meaning of the text" of this provision does "not merely provide that the law referred to in [Article 21(1)] must be interpreted consistently with human rights" but also that "the application of such law must be consistent with human rights." 91 The Appeals Chamber in Lubanga spoke to this understanding of Article 21(3) by advancing that the Court

85. See Prosecutor v. Bemba, ICC-01/05-01/08-320, Fourth Decision on Victims' Participation, I 16 (Dec. 12, 2008), https://www.icc-cpi.int/CourtRecords/CR2008_07861.PDF [https://perma.cc/5WVC-Z24P].

86. Prosecutor v. Katanga, ICC-01/04-01/07-257, Decision on the Joinder of the Cases against Germain Katanga and Mathieu Ngudjolo Chui, at 7 (Mar. 10, 2008), https://www.icccpi.int/CourtRecords/CR2008_01129.PDF [https://perma.cc/U8N9-RZHC].

87. Rebecca Young, supra note 83, at 201.

88. Prosecutor v. Bashir, ICC-02/05-01/09-3, Decision on the Prosecution's Application for a Warrant of Arrest Against Omar Hassan Ahmad Al Bashir, \ 44 (Mar. 4, 2009), https://www.icccpi.int/CourtRecords/CR2009_01517.PDF [https://perma.cc/4D99-SCJH].

89. ZeEgERS, supra note 83 , at 88.

90. Young, supra note 83, at 193.

91. Dapo Akande, Sources of International Criminal Law, in The OXford Companion to INTERNATIONAL CRIMINAL Justice 46-7 (Cassese ed., 2009). 
is to not only interpret the Court's framework but also "the application of the law applicable under the Statute subject to internationally recognised human rights." ${ }^{92}$ The Chamber resolutely asserted the relevance of ensuring consistency with human rights norms in stating that "[h]uman rights underpin the Statute; every aspect of it" and declaring that "[i]ts provisions must be interpreted and more importantly applied in accordance with internationally recognized human rights. ${ }^{93}$

The Court's application of Article 21(3) as requiring that the framework of the Court is interpreted and applied in accordance with international human rights norms and principles is particularly notable in regards to issues concerning victim participation and reparations. The Court focused heavily on ensuring consistency with human rights norms in establishing a reparations regime in Lubanga which mandates that "the Court shall treat the victims with humanity and it shall respect their dignity and human rights, and it will implement appropriate measures to ensure their safety, physical and psychological well-being and privacy." ${ }^{94}$ Noting Article 21(3)'s role in ensuring that decisions regarding reparations "must be consistent with internationally recognized human rights," the Chamber looked to "the jurisprudence of the regional human rights courts and the national and international mechanisms and practices that have been developed in this field" in finding that "the right to reparations is a well-established and basic human right, that is enshrined in universal and regional human rights treaties." ${ }^{95}$

The issue of victim participation reveals the same. On the "question [of] whether a deceased person may be recognized as a victim of the case," Article 21(3) was referenced as requiring the Chamber to ensure that this question was resolved "in conformity with" human rights jurisprudence contemplating the rights of deceased victims. ${ }^{96}$ Based on the Inter-American Court of Human Rights finding that deceased victim's rights, including to compensation, transfer to the victim's heirs by succession, the Court in Bemba similarly found that the Court should recognize "successors of a deceased person [as] exercise[ing] the rights of deceased persons in proceedings in order to safeguard claims for any future reparations." ${ }^{.97}$

92. Prosecutor v. Lubanga, ICC-01/04-01/06-772, Judgment on the Appeal of Mr. Thomas Lubanga Dyilo Against the Decision on the Defence Challenge to the Jurisdiction of the Court Pursuant to Article 19(2)(a) of the Statute of 3 October 2006 (Dec. 13, 2006), I 36, https://www.icc-cpi.int/CourtRecords/CR2007_01307.PDF [https://perma.cc/9E6L-PCV5].

93. Id. $\ 37$ (emphasis added).

94. Prosecutor v. Lubanga, ICC-01/04-01/06-2904, Decision Establishing the Principles and Procedures to be Applied to Reparations, I 190, (Aug. 7, 2012), https://www.icc-cpi.int/ CourtRecords/CR2012_07872.PDF [https://perma.cc/R99A-NCXH].

95. Id. ๆ 184-6.

96. Prosecutor v. Bemba, ICC-01/05-01/08-320, Fourth Decision on Victims' Participation, qศ 40, 44-6 (Dec. 12, 2008), https://www.icc-cpi.int/CourtRecords/CR2008_07861.PDF [https://perma.cc/5WVC-Z24P].

97. Id. (citing Case of Aloeboetoe et al., v. Suriname, Judgement, InTER-Am Ct. H.R., ๆ 54 (Sep. 10, 1993); Case of Garrido and Baigorria v. Argentina, Judgement, INTER-AM CT. H.R., 950 
In Katanga et al., the Presidency took the obligation to ensure human rights consistency a step further to give it practical meaning. Here, the Presidency found that when considering the Court's provisions under human rights principles, they "must be interpreted in a practical and effective, rather than theoretical and illusory, manner." ${ }^{98}$ Thus, the Court must go beyond theoretically recognizing that a provision is compatible with human rights and ensure that implementation is carried out in a manner that is also consistent with human rights by making the rights "effective and tangible" upon implementation. ${ }^{99}$

This understanding was exampled in regards to the "area within which article $21(3)$ is of most practical interest to the Court" 100 - fair trial rights and the rights of the accused. On the question of the right of an accused to family visits, the Presidency of the Court was guided by Article 21(3) to ensure that its decision was in line with "internationally recognised human right standards" and laws which "clearly acknowledg[e] that a detained person has the right to receive family visits." ${ }^{101}$ In so doing, the Presidency made clear that in recognizing the accused's right to family visits under international law, the Court must ensure that implementation is done in a manner that makes the right "effective and tangible" to the accused. ${ }^{102}$

The Court's case law has thus demonstrated a steady interpretation of Article 21(3) as mandating that "the ICC must interpret and apply all law in a manner consistent with international[ly] recognized human rights"103 and in a perceptible manner which makes these rights applicable in practice. Yet, as noted above, instances where the Court views human rights as not merely mandating consistency with human rights in its interpretations of the Court's texts, but as actively guiding interpretation as a source of law, call into question whether the Court has a consistent approach to the scope of human rights influence.

This expanded approach was hinted in a separate and concurring opinion examining whether victims had the right to participate in Lubanga's appeal of the confirmation of charges decision. ${ }^{104}$ Judge Sang-Hyun Song's opinion importantly acknowledged Article 21(3)'s role in mandating consistency with

(Aug. 27, 1998)).

98. Prosecutor v. Katanga et al., ICC-RoR217-02/08-8, Decision on “Mr. Mathieu Ngudjolo's Complaint Under Regulation 221(1) of the Regulations of the Registry Against the Registrar's Decision of 18 November 2008," 1 31, (Mar. 10, 2009), https://www.icc-cpi.int/CourtRecords/ CR2009_02787.PDF [https://perma.cc/6EZC-9NUX].

99. Id.

100. Young, supra note 83, at 200. See Bemba, ICC-01/05-01/08-320, ๆ 17.

101. Katanga et al., ICC-RoR217-02/08-8, ๆ 27.

102. Id. $\mid 31$.

103. Irving, supra note 66, at 838-9.

104. Prosecutor v. Lubanga, ICC-01/04-01/06-925, Decision of the Appeals Chamber on the Joint Application of Victims a/0001/06 to a/0003/06 and a/0105/06 concerning the "Directions and Decision of the Appeals Chamber" of 2 February 2007, 1 29-30 (June 13, 2007), https://www.icccpi.int/CourtRecords/CR2007_03066.PDF [https://perma.cc/MQ3N-JPSU]. 
international human rights norms when deciding the question before it. ${ }^{105}$ However, it went further in demonstrating a willingness to consider human rights norms when evaluating the interest of victims to participate before the Court by looking to human rights jurisprudence which supports victims' right of access to justice. ${ }^{106}$ Importantly, the opinion noted that in regards to the question of whether human rights support victims' right to participate in criminal proceedings, human rights jurisprudence is silent. Despite acknowledging that this human rights "jurisprudence does not stipulate that victims have a human right to participate in criminal proceedings," it displayed a human rights-based approach to the question by reading beyond only the rights explicitly set out in human rights law and jurisprudence. ${ }^{107}$ Instead, it recognized that because victims' "special interest that perpetrators responsible for their suffering be brought to justice" is protected under international human rights norms, and because "article 21 (3) of the Statute obliges the Court to interpret and apply the Statute in consistence with internationally recognized human rights," this should be taken into account when considering the "interests" of the victims in criminal proceedings. ${ }^{108}$

The separate opinion's logic was a nod to the notion that the rights of victims before the Court can emanate from the essence of human rights law and jurisprudence, and not just from its plain letter. In historical jurisprudence, it demonstrates the beginning of an expanded view of human rights as providing the Court with norms for which the Court's legal text must be consistent and a body of law and jurisprudence to source its interpretation.

As detailed above, this shifting perspective is plain in the Court's proceedings on the destruction of cultural heritage whereby human rights laws play a role in guiding the interpretation and application of the war crime under Article $8(2)(e)(i v)$, the gravity of the crimes in regards to the Prosecution's investigation and the Chamber's sentencing considerations, and victim participation and reparations. As a central component in the Court's analysis and decision making, the role of human rights in the proceedings concerning cultural heritage is emblematic of the Court's trend towards a more leading role of human rights in the interpretation and application of its own provisions.

\section{ii. The Court's Interpretation and Application of Article 21(3): More Recent Approach}

It has not been long since the closure of the Al Mahdi proceedings, with $\mathrm{Al}$

105. Prosecutor v. Lubanga, ICC-01/04-01/06-925, Separate opinion of Judge Sang-Hyun Song, Decision of the Appeals Chamber on the Joint Application of Victims a/0001/06 to a/0003/06 and a/0105/06 concerning the "Directions and Decision of the Appeals Chamber" of 2 February 2007, ๆ 16 (June 13, 2007), https://www.icc-cpi.int/CourtRecords/CR2007_03066.PDF [https:// perma.cc/3CGJ-55YU].

106. Id. ๆ 14.

107. Id.

108. Id. ๆ 16. 
Mahdi's transfer to serve his sentence as recently as March $2019,{ }^{109}$ the Appeals Chamber's judgment on reparations issued in March 2018, ${ }^{110}$ and the judgment and sentence issued in September 2016. ${ }^{111}$ Yet, a number of decisions issued in the closing and aftermath of the Al Mahdi proceeding lend support to the suggestion that the proceedings against $\mathrm{Al}$ Mahdi for the destruction of cultural heritage are demonstrative of a movement of the Court's orientation on human rights influences for the interpretation and application of the Court's legal texts.

In regards to the degree to which human rights influence the interpretation and application of the Court's legal framework, and the understanding of Article 21(3) role in this regard, the Court has increasingly demonstrated an expanded willingness to go beyond its former application of Article 21(3) as a "human rights consistency test" which limited it to ensuring that human rights "underpin" its statutory interpretation, and to increasingly allowing human rights to take a more prominent role in guiding the Court's interpretation.

This is evident with the Court's recent use of human rights law and jurisprudence to interpret crimes within the Rome Statute. In a decision within the Situation in the Republic of Burundi in late 2017, the Court examined the length and severity required of a detention to find the commission of the "crime of imprisonment or other severe deprivation of physical liberty, within the meaning of Article 7(1)(e) of the Statute," and looked to human rights jurisprudence finding that even detention for "a relatively short time" constituted a violation. ${ }^{112}$ The Court's analysis explicitly acknowledged Article 21(3)'s mandate of "interpreting and applying the Rome Statute in conformity with internationally recognized human rights." 113

In the Situation concerning Bangladesh and Myanmar, the Pre-Trial Chamber similarly looked to international human rights law and considerations when interpreting both the crime against humanity of "other inhumane acts" and why this crime may also fall within the Chamber's "rationale of its determination as to the Court's jurisdiction in relation to the crime of deportation." 114 The Court

109. Ahmad Al Faqi Al Mahdi Transferred to UK Prison Facility to Serve Sentence, InT'L CRIM. Ст. (May 3, 2019), https://www.icc-cpi.int/Pages/item.aspx?name=pr1451 [https://perma.cc/ MM48-9RU9].

110. Prosecutor v. Al Mahdi, ICC-01/12-01/15-259-Red2, Judgment on the Appeal of the Victims Against the 'Reparations Order' (Mar. 8, 2018), https://www.icc-cpi.int/CourtRecords/ CR2018_01623.PDF [https://perma.cc/6M63-U9H9].

111. See generally Prosecutor v. Al Mahadi, ICC-01/12-01/15-171, Judgement and Sentence (Sept. 27, 2016), https://www.icc-cpi.int/courtrecords/cr2016_07244.pdf [https://perma.cc/4MSXEFFN].

112. Situation in the Republic of Burundi, ICC-01/17-X-9-US-Exp, Public Redacted Version of "Decision Pursuant to Article 15 of the Rome Statute on the Authorization of an Investigation into the Situation in the Republic of Burundi," 25 October 2017, ๆ 68, n. 170 (Nov. 9, 2017), https://www.icc-cpi.int/CourtRecords/CR2017_06720.PDF [https://perma.cc/UM2K-FM7Y].

113. Id. n. 170.

114. Request Under Regulation 46(3) of the Regulations of the Court, ICC-RoC46(3)-01/1837, Decision on the 'Prosecution's Request for a Ruling on Jurisdiction Under Article 19(3) of the 
addressed the element of the crime of "other inhumane acts" requiring that the alleged act be "of a character similar to any other act referred to in article 7"; it clarified that this alleged act could be a human rights violations given that such a violation may "be of a character similar to the crime against humanity of persecution." 115 To be clear, the Pre-Trial Chamber does not assert that to meet this element, another crime under article 7 must be fully set out, but instead that the act is merely similar to that of another under article 7 . Therefore, in its decision, the Chamber looked to human rights violations against the Rohingya Muslim population deported into Bangladesh-namely the violation of "arbitrarily depriv[ing an individual] of the right to enter one's own country"- to find that this human rights violation was similar in character to that alleged within the crime of persecution and that this violation was an inhumane act which causes great suffering in the population. ${ }^{116}$

The case law in the Situation in Burundi and Situation in Bangladesh and Myanmar above reveals decisions that enter the territory of interpreting the crimes within the Rome Statute as guided by international human rights law, instead of the more secondary role of ensuring consistency with human rights norms and principles.

This extends to fundamental principles set out within the Court's texts as well. Again in the Situation in Bangladesh and Myanmar, and based on the Chamber's interpretation of the crime of "other inhumane acts," the Chamber extended its landmark finding that the Court has jurisdiction over some crimes when at least "one element of this crime or part of it is committed on the territory of a State Party" as applying to the crime of "other inhumane act" as well. ${ }^{117}$ It was reasoned that because the act of prohibiting victims from returning to their country - the human rights violation identified - occurred in the territory of a State Party, the Court's jurisdiction determination applied. ${ }^{118}$ It is a decision whereby human rights were key to the Court's interpretation of the crime and the Court's ability to include this crime as one of the crimes applicable to its determination on jurisdiction when limited elements of the crime occurred under Article 12(2)(a).

In the Court's admissibility decision in the case against Saif Gaddafi, the Court "interpreted the relevant provisions in light of [human rights] jurisprudence, including from other courts, in relation to the ne bis in idem principle." 119 While it did so with reference to Article 21(3), its application of this

Statute, ๆ 74 (Sept. 6, 2018), https://www.icc-cpi.int/CourtRecords/CR2018_04203.PDF [https:// perma.cc/7R8F-QARD].

115. Id. 977.

116. Id.

117. Id. $ๆ \uparrow 71,78$.

118. Id.

119. Prosecutor v. Gaddafi, ICC-01/11-01/11-695, Judgment on the Appeal of Mr. Saif AlIslam Gaddafi Against the Decision of Pre-Trial Chamber I Entitled Decision on the 'Admissibility Challenge by Dr. Saif Al Islam Gadafi Pursuant to Articles 17(1)(c), 19 and 20(3) of the Rome Statute' of 5 April 2019, I 62 (Mar. 9, 2020), https://www.icc-cpi.int/CourtRecords/ 
provision moved beyond the more limited interpretation whereby the Court's decision is checked for consistency against human rights norms. ${ }^{120}$ The decision took the same approach to the question of domestic amnesties' effect on proceedings before the Court with reliance upon jurisprudence from human rights courts. ${ }^{121}$

This inclination towards an increased role of human rights law as guiding the interpretation and application of the Court's legal provision is suggested in a separate opinion of Judge Luz del Carmen Ibáñez Carranza in the Situation in Afghanistan. While the separate opinion strongly supports interpreting Article 21(3) as mandating that human rights underpin the provision of the Court by stating that the provision "commands that our interpretation "must be consistent with internationally recognized human rights," 122 it also advocates for international human rights law to influence "statutory interpretation" in a manner which is "dependent on the evolving recognition of human rights." 123 Judge Ibáñez Carranza explained that the "principle of evolving interpretation is based on the understanding that "treaties are living instruments, whose interpretation must go hand in hand with evolving times and current living conditions," and applies to the Rome Statute as a "living instrument that must be read in keeping with the conditions of our times." 124

As noted above, Article 21 does not offer international human rights law as a source of law to be applied among the hierarchy of applicable laws set out in Article 21(1), but merely a tool to ensure that the interpretation and application of the Court's legal texts are not in conflict with human rights norms as provided in Article 21(3). Yet, the interpretation of Article 8(2)(e)(iv) in Al Mahdi, which carried the war crime of attacks on cultural property beyond that of a crime against specially protected sites and building to its recognition as a crime against the human rights of individuals who value the property, are emblematic of the expanding role of international human rights by allowing it to guide the interpretation of crimes under the Statute.

\section{The Court's Approach to Issues of Human Rights Obligations or Violations}

The above demonstrates that the influence of human rights considerations for the interpretation and application of its legal framework, and Article 21(3)'s mandate, have progressed, and the Al Mahdi proceedings have exampled the

\footnotetext{
CR2020_00904.PDF [https://perma.cc/C2FR-T6AQ].

120. Gaddafi, ICC-01/11-01/11-662, १ฯ 34-45.

121. Id. ๆๆ 61-72.

122. Situation in Afghanistan, ICC-02/17-138-Anx-Corr, Separate Opinion of Judge Luz del Carmen Ibáñez Carranza, Judgment on the Appeal Against the Decision of Pre-Trial Chamber II on the Authorisation of an Investigation into the Situation in the Islamic Republic of Afghanistan, I 7 (Mar. 5, 2020), https://www.icc-cpi.int/RelatedRecords/CR2020_00861.PDF [https://perma.cc/ N8FA-G9KL] (emphasis added).

123. Id.

124. Id.
} 
degree to which the Court's view of the role of human rights has expanded. Reversely, the Court has also displayed consistency in a very different regard, namely, where it will not entertain or engage with human rights considerations.

\section{i. Issues Concerning the Merits of Human Rights Concerns: Historical Approach}

Where the Court's approach to human rights considerations has been consistently hesitant is when asked to take into account human rights issues which would require the Court to make a finding or take a position as to whether human rights violations occurred, particularly if the allegation is that the human rights violation was committed in a domestic system. Therefore, although the human rights issues raised might directly affect the proceedings before the Court, a line has been drawn on engaging with human rights in this regard.

Two notable decisions demonstrate the Court's strong objection to being drawn into the role of a human rights court. The first provides a clear illustration of the Court's position in the Appeals Chamber's judgment concerning the admissibility of the case against Abdullah Al-Senussi. When the defense argued that the case against Al-Senussi was admissible before the Court because Libya was not "able" to prosecute the case against Al-Senussi, in part, due to alleged human rights violations he suffered in detention in Libya, which irrevocably jeopardized his right to a fair trial, the Pre-Trial Chamber found, with the Appeals Chamber affirming, that allegations of human rights violations should not, apart from in limited circumstances, "play a role in the determination as to whether a case is inadmissible." 25 Accordingly, the Appeals Chamber refused to engage with human rights considerations which required a finding on the merits of the allegations. This position was maintained despite the defense raising that the alleged human rights violations had a direct bearing on the question before the Court of whether fair trial rights violations should be assessed as demonstrating that Libya did not seek to genuinely bring Al-Senussi to justice. ${ }^{126}$ In so doing, the Appeals Chamber notably declared that "the Court was not established to be an international court of human rights, sitting in judgment over domestic legal systems to ensure that they are compliant with international standards of human rights," and is not a "mechanism to complain about human rights violations." 127

The second example arises in the case against Germain Katanga. Here, the Court similarly rejected what it perceived to be a request to act "as a court of

125. Prosecutor v. Al -Senussi, ICC-01/11-01/11-565, Judgment on the Appeal of Mr. Abdullah Al-Senussi Against the Decision of Pre-Trial Chamber I of 11 October 2013 Entitled 'Decision on the Admissibility of the Case Against Abdullah Al-Senussi,' I 169 (July 24, 2014), https://www.icc-cpi.int/CourtRecords/CR2014_06755.PDF [https://perma.cc/7RZV-QC56].

126. Prosecutor v. Al-Senussi, ICC-01/11-01/11-474, Document in Support of Appeal on behalf of Abdullah Al-Senussi against Pre-Trial Chamber I's 'Decision on the Admissibility of the Case Against Abdullah Al-Senussi,' qฯ 27, 29, $92-93$ (Nov. 4, 2013), https://www.icccpi.int/CourtRecords/CR2013_08654.PDF [https://perma.cc/7RZV-QC56].

127. Al-Senussi, ICC-01/11-01/11-565, \219. 
human rights- [when] it was never conceived as such." ${ }^{\prime 28}$ The Court exampled its proclivity against considering human rights issues which require it to weigh in on the existence of violations when asked to address the prolonged detention of witnesses transferred from detention in the DRC to assist the Court with evidence, and who, while in the Netherlands, sought asylum. The Court was requested to interpret Article 93(7) and Rule 192(4) concerning the transfer and return of detained witnesses to the custody of the Court under Article 21(3) to determine the legitimacy of their continued detention in The Hague while the witnesses' asylum applications remained pending, triggering issues of their rights against arbitrary detention. Here, the Chamber strongly found it lacked the competence to adjudicate this human rights concern. ${ }^{129}$ While the Court has recognized that Article 21(3) requires the Court's own framework to be interpreted and applied in accordance with human rights, in this decision it decisively confirmed its position that Article 21(3) cannot be extended into requiring the Court "to ensure that States Parties respect internationally recognised human rights in their domestic proceedings," or that the Court must engage in determining whether human rights violations were committed. ${ }^{130}$

The Court has regularly limited its willingness to engage on human rights issues that involve a domestic system or its proceedings. This is evident in a number of decisions in which the Court limited its purview on adjudicating issues arising from the Court's proceedings but which involved the domestic system of a State. Despite the fact that the Court was asked to consider the interpretation and application of its own provisions in line with internationally recognized human rights considerations, it has shown reluctance when such a consideration required the Court to weigh in on the domestic actions of States.

This reluctance is evident in the Katanga case whereby the Court considered its obligation "to take all protective measures necessary to prevent the risk witnesses incur on account of their cooperation with the Court." 131 Here, the Court restricted its obligation to engage in this human rights concern to situations regarding "protecting witnesses from the risk they face on account of their testimony." 132 Again, the Chamber refused to interpret Article 21(3) to require

128. Prosecutor v. Katanga, ICC-01/04-01/07-3405-tENG, Decision on the Application for the Interim Release of Detained Witnesses DRC- D02-P-0236, DRC-D02-P-0228 and DRC-D02-P0350, ๆ 27 (Oct. 1, 2013), https://www.icc-cpi.int/CourtRecords/CR2013_08767.PDF [https:// perma.cc/H5DA-LYR5].

129. Id.

130. Id.

131. Prosecutor v. Katanga et al., ICC-01/04-01/07-3003-tENG, Decision on an Amicus Curiae Application and on the "Requête tendant à obtenir présentations des témoins DRC D02 $\mathrm{P}$ 0350, DRC D02 P 0236, DRC D02 P 0228 aux autorités néerlandaises aux fins d'asile" (articles 68 and 93(7) of the Statute), I 61 (June 9, 2011), https:/www.icc-cpi.int/CourtRecords/ CR2011_07370.PDF [https://perma.cc/V6DK-2743].

132. Id.; see also Prosecutor v. Katanga, ICC-01/04-01/07-3033, Decision on the Security Situation of Three Detained Witnesses in Relation to their Testimony Before the Court (art. 68 of the Statute) and Order to request cooperation from the Democratic Republic of the Congo to 
it to ensure human rights or adjudicate their violation in the domestic system, stating that "Article 21(3) of the Statute does not place an obligation on the Court to ensure that States Parties properly apply internationally recognised human rights in their domestic proceedings," and "only requires the Chambers to ensure that the Statute and the other sources of law set forth at article 21(1) and 21(2) are applied in a manner which is not inconsistent with or in violation of internationally recognized human rights." 133

The Court's hesitancy to wade into allegations of human rights violations in domestic systems was reiterated in Lubanga, where the Court held that violations of the accused's rights during arrest and detention by domestic authorities could only be considered if arrest or detention was carried out in cooperation with the Court. Thus, unless the allegation stemmed from the Court's own actions or a state's actions carried out at the request of the Court, it maintained the position that it will refrain from considering the human rights issues, even if the allegations concern irregularities in the domestic arrest or detention procedure and have a bearing on the proceedings before the Court. ${ }^{134}$

This position can even be seen as extending into instances where human rights concerns arise when the accused is not before the Court. For example, in the case against Joseph Kony, Vincent Otto, Okot Odhiambo, and Dominic Ongwen, the Appeals Chamber addressed whether four accused, who were subject to an ICC arrest warrant but at large at the time of the decision, had the right to be individually legally represented for the admissibility proceedings being considered by the Pre-Trial Chamber. Although a determination on the admissibility of the case before the ICC would undoubtedly have an impact on the accused's fair trial rights, the Appeals Chamber found no error in the PreTrial Chamber's decision to appoint one defense counsel to represent all four of the accuseds' interests in the proceedings, despite defense counsel's concerns of conflict and that the "rights of the persons subject to the warrants of arrest were not properly safeguarded in the proceedings." 135 The Chamber held that "internationally recognised human rights standards do not necessarily extend all the rights enshrined in article 67 of the Statute to persons who have not yet been

Provide Assistance in Ensuring their Protection in Accordance with Article 93(1)(j) of the Statute, ๆ 38 (June 22, 2011).

133. Katanga et al., ICC-01/04-01/07-3003-tENG, 962.

134. Prosecutor v. Lubanga, ICC-01/04-01/06-512, Decision on the Defence Challenge to the Jurisdiction of the Court Pursuant to Article 19(2)(a) of the Statute, at 10-11 (Oct. 3, 2006), https://www.icc-cpi.int/CourtRecords/CR2006_03214.PDF [https://perma.cc/5J7K-R8L5].

135. Prosecutor v. Katanga et al., ICC-RoR217-02/08-8, Decision on “Mr. Mathieu Ngudjolo's Complaint Under Regulation 221(1) of the Regulations of the Registry Against the Registrar's Decision of 18 November 2008," ๆף 11, 68 (Mar. 10, 2009), https:/www.icc-cpi.int/CourtRecords/ CR2009_02787.PDF [https://perma.cc/6EZC-9NUX]. See also Prosecutor v. Kony et al., ICC02/04-01/05-350, Submission of Observations on the Admissibility of the Case Under Article 19(1) of the Statute (Nov. 18, 2008), https://www.icc-cpi.int/CourtRecords/CR2015_01618.PDF [https://perma.cc/ZAY2-CRXT]. 
surrendered to the Court or appeared voluntarily before it."136

It could be argued that a human rights-based approach to protecting the rights of an accused subject to an arrest warrant before the Court might have recognized that admissibility proceedings without separate legal representation capable of making individual submissions on behalf of each accused could ultimately impact their fair trial rights. Yet, the Court's decision is also consistent with its reluctance to engage in determinations on human rights, particularly in domestic proceedings or systems. Using similar logic to its position set above, the Court refused to apply human rights standards when the accused had not surrendered to or appeared before the Court, explaining that to do so would require it to extend beyond the human rights applicable to the Court's proceedings and to determine whether certain human rights must be afforded to an individual located in another country - thus, essentially engaging the Court in an exercise of determining that certain human rights should be afforded and requiring the state to afford these rights.

Therefore, the Court has developed consistency in its relationship with human rights considerations which require the Court to weigh in on the commission of human rights allegations. The Court's historical approach has drawn a line at going so far as engaging with human rights issues such that these considerations become the driving force for the Court's work or motivation for its actions and require determinations that ultimately impact domestic legal systems.

\section{ii. Issues Concerning the Merits of Human Rights Concerns: More Recent Approach}

While the Court's approach to human rights considerations has shifted towards a greater willingness to allow them to influence and guide the interpretation and application of the Court's legal framework, the same is not true of the Court's approach to more substantive human rights claims. Here, the Court has remained steady in its approach to weighing in on the merits of claims in regards to instances of human rights being violated. $b$ decisions demonstrate this resolve.

The Court's decision in response to the request by the defense of Jean-Pierre Bemba Gombo for compensation following his acquittal is informative of both approaches to human rights by the Chamber; both of the Chamber's increased willingness to use international human rights law and jurisprudence as a source of law in its interpretation and application of the Court's provisions, and in the Chamber's steady reluctance to engage with claims of human rights violations. The request, which claimed compensation in two regards, first asserted that compensation was due under Article 85 of the Rome Statute, allowing for compensation claims from an accused who can demonstrate the existence of a

136. Prosecutor v. Kony et al., ICC-02/04-01/05-408, Judgment on the Appeal of the Defence Against the 'Decision on the Admissibility of the Case Under article 19 (1) of the Statute' of 10 March 2009, ๆ 66 (Sept. 16, 2009), https://www.icc-cpi.int/CourtRecords/CR2009_06675.PDF [https://perma.cc/6G8W-V56V]. 
"miscarriage of justice."137 The Court's interpretation of the meaning of "miscarriage of justice" under Article 85 leaned heavily on international human rights law and jurisprudence, demonstrating again the Court's increased willingness to view human rights as a source of law for the interpretation of the Court's provisions. ${ }^{138}$

However, the Court's analysis by way of human rights sources notably resulted in an interpretation which limited the scope of "miscarriage of justice" such that the Court's mandate under the provision did not extend to considering claims of violations to the accused's rights during proceeding which would signify that a miscarriage of justice had occurred. ${ }^{139}$ While the Court affirmed that the provision is meant to "provid[e] suspects and accused persons with a full range of guarantees against serious violations of their fundamental right to a fair trial," human rights law and jurisprudence were relied upon to show the lack of comparable or equivalent human rights. ${ }^{140}$ To this, the Chamber found that the term "miscarriage of justice was never meant to address situations falling within the scope of the dynamics inherent to the natural developments of criminal proceedings," and that the violations which deserve compensation instead "encompass scenarios of an exceptional nature, substantially differing from those that are typical of procedural phases of a trial." ${ }^{141}$ As the question raised before the Chamber fell within the scope of Article 85, the Court was obligated to consider the alleged miscarriage of justice. However, the Court's decision conveyed its reluctance to being drawn into questions more akin to that of a human rights court.

This reluctance was further confirmed in the Court's approach to the defense's second argument for compensation on the basis that Bemba's right to property was violated by the Court's alleged negligence in freezing and seizing Bemba's property. Here, the Court clearly demonstrated its unwillingness to engage in determining the occurrence of a human rights violation by bypassing adjudication of the violation alleged and instead finding that it "falls outside the scope and purpose of proceedings under article 85(3)."142 This approach was confirmed by the Appeals Chamber, which reiterated that the Pre-Trial Chamber "never rendered 'a final determination of the question of whether [Mr. Bemba's] fundamental human rights have been violated by the seizure and destruction of his property." $" 143$

137. Rome Statute, supra note 2, art. 85 .

138. Prosecution v. Bemba, ICC-01/05-01/08-3694, Decision on Mr. Bemba's Claim for Compensation and Damages, 9ף 33-47 (May 18, 2020), https://www.icc-cpi.int/CourtRecords/ CR2020_01979.PDF [https://perma.cc/E2HY-C2PK].

139. Id.

140. Id. $\mid 33$.

141. Id.

142. Id. 64.

143. Prosecution v. Bemba, ICC-01/05-01/08-3697, Decision on the Request for Leave to Appeal the 'Decision on Mr. Bemba's Claim for Compensation and Damages,' 16 (Oct. 1, 2020), https://www.icc-cpi.int/CourtRecords/CR2020_05471.PDF [https://perma.cc/A82A-EATL]. 
Almost concurrently, the Appeals Chamber similarly refused to engage with a request from another acquitted accused, Laurent Gbagbo, which requested a finding that Gbagbo was denied justice in regards to proceedings concerning his conditional release after acquittal. ${ }^{144}$ Conclusively confirming its consistent approach, the Chamber dismissed the request in limine finding no "legal basis or procedural avenue in the Statute or Rules of Procedure and Evidence on the basis of which he would be entitled to seek a finding by the Appeals Chamber concerning a potential denial of justice in these circumstances." ${ }^{\prime 145}$ Linking its dismissal to its unwillingness to weigh in on human rights violations, the Chamber noted that "even if the Appeals Chamber were to find that there is a legal basis for the Request for a Finding of Denial of Justice on the basis of international human rights law," dismissal in limine would still be warranted. ${ }^{146}$

The same was displayed by the Trial Chamber in Al Hassan, which showed consistent hesitation at jumping into the substance of human rights allegations that arose within a June 2020 application from the Defense requesting termination of the proceedings against the accused. ${ }^{147}$ The request was made based on allegations that the charges against Al Hassan were "irrevocably tainted by the poisonous fruits of torture, cruel, inhuman and degrading treatment ('CIDT'), and severe human rights violations," with the "Prosecution aggravate[ing] and compound[ing] the effects of the torture undergone by Mr. Al Hassan," such that the "constituent elements of a fair trial cannot be pieced together." 48 While the Defense's allegations of the human rights violations of torture and cruel, inhuman, and degrading treatment were integral to the Defence request, the Trial Chamber's decision carefully stayed within the bounds of solely adjudicating the request to terminate the proceedings and not making a finding on the merits of the alleged violations. ${ }^{149}$ To do this, the Trial Chamber first found that the "key issue for the Chamber's consideration is the issue of attributability of alleged violations to the Prosecution" and second, set out that it would not decide whether or not the violations were indeed committed, but to decide the Prosecution's attributability, would "take the Defence's allegations of torture/CIDT at their highest and . . .

144. Prosecutor v. Gbagbo et al., ICC-02/11-01/15-1376-Red, Decision Dismissing in Limine Mr. Laurent Gbagbo's Request for a Finding of a Denial of Justice, 9ף 1-4 (Sept. 2, 2020), https://www.icc-cpi.int/CourtRecords/CR2020_05082.PDF [https://perma.cc/P4NM-S3JQ].

145. Id. 96.

146. Id. 97.

147. Prosecutor v. Al Hassan, ICC-01/12-01/18-885-Corr-Red3, Public Redacted Version of 'Corrigendum to "Defence Request to Terminate the Proceedings" ๆף 1-3 (June 16, 2020) (public redacted corrigendum July 28, 2020), https://www.icc-cpi.int/CourtRecords/CR2020_04689.PDF [https://perma.cc/2FPG-PF4V].

148. Id. $₫$ ๆ $1-3$.

149. Prosecutor v. Al Hassan, ICC-01/12-01/18-1009-Red, Public redacted version of 'Decision on the Defence Request to Terminate the Proceedings and Related Requests', 80 (Aug. 24, 2020), https://www.icc-cpi.int/CourtRecords/CR2020_05897.PDF [https://perma.cc/XSN9JZ78]. 
analyse the remainder of the Defence allegations on this basis." ${ }^{150}$ In deciding to reject the Defence's request to terminate the proceedings, the Trial Chamber was clear that it came to this decision without needing to make any "determinations on the Defence's allegations of torture and cruel, inhuman and degrading treatment;" thus reinforcing the consistent approach against engaging in the merits of human rights claims. ${ }^{151}$

\section{CONCLUSION}

There is little doubt that human rights played a central role in the proceedings before the Court in regard to the war crime of destruction of cultural property and heritage. The influence of human rights considerations touched nearly every phase of the proceedings - from the preliminary examination to reparations - underlining the Court's view of the crime as being intrinsically linked to human rights of the individuals and communities who valued the buildings and objects destroyed and damaged. In finding that the importance of the cultural property and heritage attached to the culture, and rights of people are "an essential component of the charges" under Article 8(2)(iv), ${ }^{152}$ the Court signified the degree to which human rights influenced the Court's interpretation of the crime.

It is also clear that the $A l$ Mahdi proceedings fit within a discernable trend towards a greater influence of human rights in the proceedings before the Court regarding the role of human rights law in interpreting and applying the Court's statutory framework. While an examination of the Court's historical approach to discrete human rights considerations reveals a firm hesitancy towards human rights considerations which require the Court to weigh in on human rights allegations, even in its more recent jurisprudence, the same consistency is not evidence in regards to human right's role in interpreting and applying the Court's legal text. The analysis above demonstrates that the proceedings for the crime of destruction of cultural property and heritage are emblematic of a trend towards not only viewing human rights as a tool for ensuring consistency but as a guiding force in the interpretation and application of the Court's legal texts in a manner more consistent with viewing human rights as a source of law.

150. Id. $ๆ 80$.

151. Prosecutor v. Al Hassan, ICC-01/12-01/18-1150, Decision on Matters Related to Defence Challenges Under Article 69(7) of the Statute, I 2 (Nov. 6, 2020), https://www.icc-cpi.int/ CourtRecords/CR2020_06054.PDF [https://perma.cc/LG56-Z57H].

152. Prosecutor v. Al Mahdi, ICC-01/12-01/15-236, Reparations Order, \ 13 (Aug. 17, 2017), https:/www.icc-cpi.int/CourtRecords/CR2017_05117.PDF [https://perma.cc/WNB7-G3HZ]. 